\title{
Changes in mineral composition and depositional environments recorded in the present and past basin-fill sediments of the Kathmandu Valley, central Nepal
}

\author{
Mukunda Raj Paudel*, Yoshihiro Kuwahara and Harutaka Sakai \\ Department of Earth Sciences, Graduate School of Social and Cultural Studies, Kyushu University, Ropponmatsu, \\ Fukuoka 810-8560, JAPAN \\ * To whom correspondence should be addressed. E-mail: cs500032@scs.kyushu-u.ac.jp
}

\begin{abstract}
Surfaceand drill coresedimentsfrom theKathmandu Basin were investigated to decipher their capability to record changes in the mineral composition and depositional environment. Spatial distribution of mineral assemblages in the terrigenous sand and mud reflects different provenance of the past and present basin filled sediments. Bulk mineral assemblages in the modern sediments are controlled by supply of terrigenous detritus from the source rocks in the adjacent surrounding mountains. This suggeststheoccurrence of granitic and gneiss sourcein thenorth and metasedimentsin the eastern, western and southern part of theKathmandu Basin.
\end{abstract}

X-ray diffraction (XRD) experiment was done for the mineralogical study of the present river sediments and RB core sediments. RB core was drilled at Rabhibhawan in the western part of theKathmandu Basin (Sakai et al. 2001). All sampleswere prepared on the basis of rule adapted by Kuwahara (2001). XRD measurement were done by Rigaku X-ray Diffractometer RINT $2100 \mathrm{~V}$, using CuK $\alpha$ radiation monochromatized by a curve graphite crystal in a step counting time of 2 second. The profile fitting of obtained XRD patterns was performed with an Apple Power Macintosh computer and a scientific graphical analysis program XRD MacDiff (Petschik2000). Theresult of theindividual minerals obtained from the profile-fitting method was used for quantitative analysis. Relative amount of minerals in the sediments were determined by calibration curve obtained from integrated intensity ratio of the standard mineral to internal standard zincite

$X$-ray diffraction (XRD) analysis of greater than $2 \mathrm{~mm}$ fraction of thepresent river sediments from theKathmandu Basin shows quartz, K-feldspar, plagioclase and mica to be the dominant bulk minerals (accounting over $80 \%$ ). It shows the presence of low amounts of chlorite and calcite. Chlorite is relatively higher in the northern part than the east, west and south. Based on the study done, the mineral assemblages of the present river sediments within theKathmandu Valley are divided into two groups. The first group is rich in mica, poor in quartz and has presence of K-feldspar, plagioclase and chlorite in all samples. This group of mineral originated from Shivapuri Lekh of the granite and gneiss complex. The second group is rich in quartz and poor in mica and has presence of plagioclase, $\mathrm{K}$ feldspar and very poor chlorite. This group probably originated from metasediments in the eastern, western and southern part of theKathmandu Valley. Somesamples of this group also contain very low percentage of calcite (less than $5 \%$ ).

Mineral assemblages in the RB coresediments from 7 to 40 $m$ depth indicate the same as those encountered in the present river sediments. XRD-analysis of the greater than $2 \mathrm{~mm}$ fraction shows the presence of quartz (10-60\%), K-feldspar (2-37\%), plagioclase (2-8\%), mica (4-19\%), chlorite (2-14\%) and calcite (0-18\%). Relatively high percentages of these minerals are

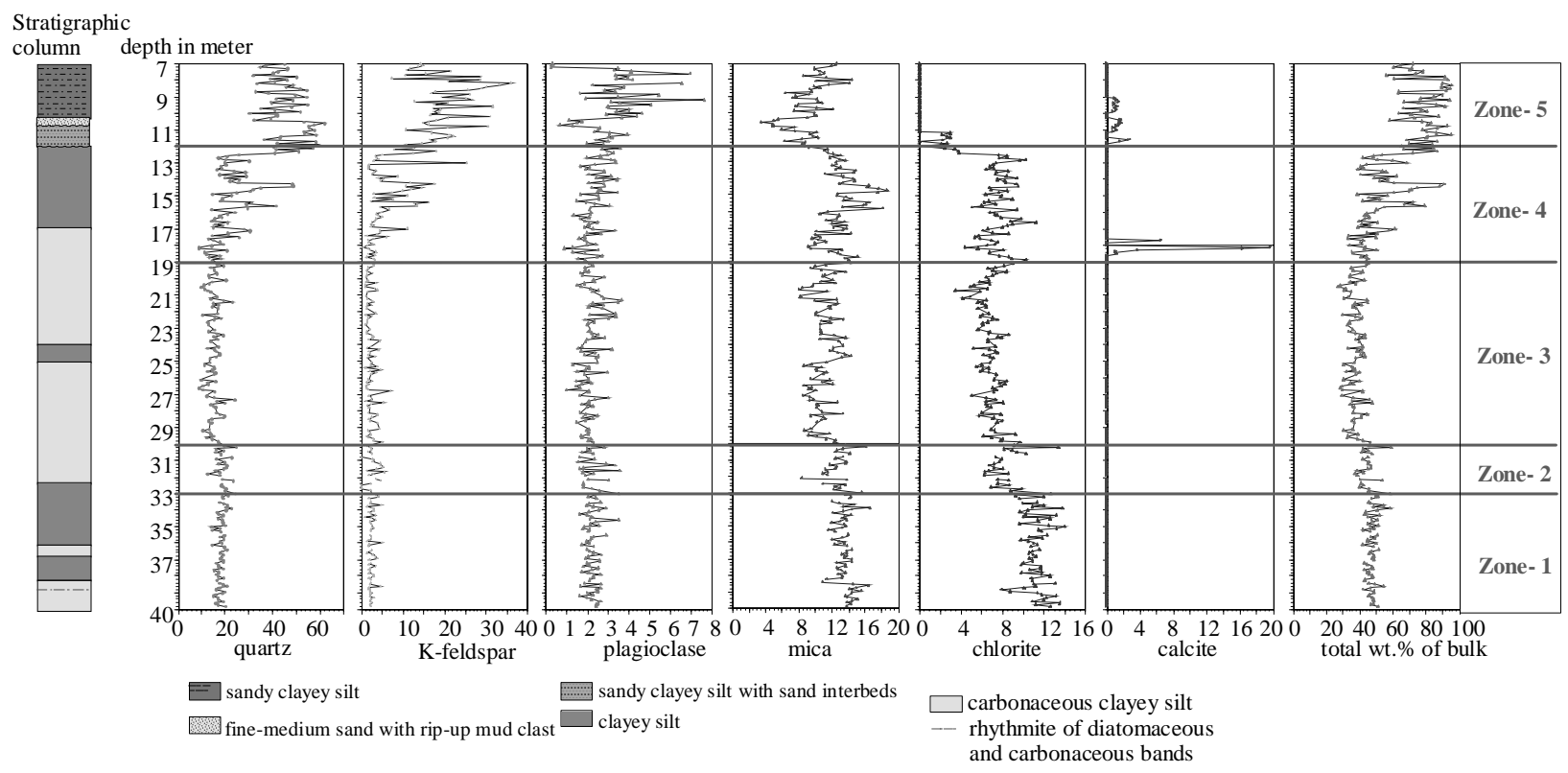

FIGURE 1. Mineralogical variation in the RB core up to $40 \mathrm{~m}$ depth 
detected above the $13 \mathrm{~m}$ depth. The trends in amount between quartz, feldspar and mica are opposite, quartz and feldspar increase when mica decreases. The trend between chlorite and mica is parallel.

On the basis of the variation of these mineral swith depth, wedivided the RB coresedimentsinto fivemineral zones (Figure 1). Zone $1(40-33 \mathrm{~m})$ is rich in chloriteand with quartz and mica higher than in zone-3. Zone-2 $(33-30 \mathrm{~m})$ is rich in chlorite with decreased total amount of the minerals. Zone-3 (30-19 m) has the lowest total amount of all minerals poor in quartz and mica. Zone-4 (19-12 $\mathrm{m}$ ) has increased whole mineral composition. Zone-5 (12-7 m) has increased quartz and feldspar (highest value), with the total amount twiceas much as in other zones.

Changes of the mineral composition of the present river sediment with respect to different directions show the provenance of the sediments to be not just one particular direction. Moreover, relatively higher percentage of chloritein the northern part of the sediments might indicate the source rock contains higher percentage of mica. South, east and west of the Kathmandu Basin contain the carbonate rocks. However, very few percentage of carbonatemineralsare detected from this site, which indicate that the carbonateminerals are dissolved within the present river.

RB drill core is located near to the Phulchoki Group of metasediments. The present river sediments flowing from metasedimentzones havevery low amount of chlorite. However, sediments of the RB core contain chlorite minerals, which are similar to the granitic and gneiss source of the Shivapuri Lekh. Variation of the mineral content in the zone 4 and 5 of RB core above $13 \mathrm{~m}$ depth are larger than the zone below $13 \mathrm{~m}$ depth, particularly, quartz, K-feldspar and mica. Similarly, different amount of mineralogical variation obtained from the drill-well JW-3 in the central part of the Kathmandu Basin (Fujii and Kuwahara 2001). Hence, such mineralogical variation with respect to the depth in the drill core sediments indicates the depositional environmental changes at thetime of deposition.

\section{References}

Fujii R, Y Kuwahara and H Sakai. 2001. Mineral composition changes recorded in the sediments from a 284-m-long drill-well in central part of the Kathmandu Basin, Nepal. J Nepal Geol Soc (Sp issue) 25:63-69

Kuwahara Y, R Fujii, Y Masudome and H Sakai. 2001. Measurement of Crystallinity and relative amount of clay mineral in the Kathmandu Basin sediments by decomposition of XRD pattern (profile fitting). J Nepal Geol Soc (Sp.Issue) 25:71-80

Lanson B.1997. Decomposition of experimental X-ray diffraction pattern (Profilefitting); A convenient way to study clay minerals. Clayand clay Miner 45:132-146

Petschick R. 2000. MacDiffVer.4.2.3, Manual Geologisch-Palaontologisches Institute Johann Wolfgang Goethe Universitat Frankfurt Main senckenberganlage 32-34, 60054 Frankfurt am Main, Germany. $58 p$

Sakai H, R Fujii and Y Kuwahara. 2001. Core drilling of the basin-fill sediments in the Kathmandu Valley for paleaeoclimatic study: preliminary results, Nepal. J Nepal Geol Soc (Sp issue) 25: 9-18 